\title{
SEXUAL DYSFUNCTION AND INCIDENCE OF DEPRESSION IN MULTIPLE SCLEROSIS PATIENTS
}

\author{
Iris Zavoreo ${ }^{1}$, Tihana Gržinčić ${ }^{2}$, Marina Preksavec ${ }^{2}$, Tomislav Madžar ${ }^{3}$ and Vanja Bašić Kes Tet, $^{1,4}$ \\ ${ }^{1}$ Neurology Department, UHC Sestre milosrdnice, Zagreb, Croatia; ${ }^{2}$ Neurology Department, GH Bjelovar, \\ Bjelovar, Croatia; ${ }^{3}$ School of Medicine, University of Zagreb; ${ }^{4}$ Faculty of Medicine, University of Osijek, Croatia
}

\begin{abstract}
SUMMARY - Multiple sclerosis (MS) is one of the most common diseases of the central nervous system and usually occurs at the age when people would be expected to be in the prime of their sexual lives. In everyday practice, sexual dysfunction is underestimated because clinicians mostly concentrate on the classic neurologic deficits and often overlook symptoms that can seriously affect the quality of life. Our study included 98 patients ( 42 men and 56 women, mean age $35 \pm 12$ years) with relapse from our MS register, with established diagnosis of relapsing remitting multiple sclerosis according to McDonald criteria. Patients completed the questionnaires (Sexual Satisfaction Scale, SSS and Beck Depression Scale BDS), and underwent neurological assessment (Expanded Disability Status Scale, EDSS). All patients were in the group with EDSS 2 to 4 points (mobile patients). There was no statistically significant difference in BDS and SSS values according to EDSS score. Correlation coefficients were calculated (BDS and SSS) for men $(\mathrm{p}=0.42)$ and women $(\mathrm{p}=0.44)$, yielding positive correlation. There was no statistically significant difference in BDS and SSS values according to gender, disease duration or immunomodulatory therapy. In our group of patients, despite low EDSS score (fully ambulatory without aid, self sufficient patients) we found positive correlation between sexual dysfunction and depression, showing that even in such patients the quality of life can be decreased. In conclusion, sexual dysfunction and depression are mostly under-recognized by neurologists because they are not part of routine testing; therefore, some additional questionnaires should be used in the evaluation in MS patients, even those with low EDSS score, in order to improve their quality of life.
\end{abstract}

Key words: Multiple sclerosis; Sexual dysfunction, physiological; Sexual dysfunction, psychological; Depression

\section{Introduction}

Multiple sclerosis (MS) is a chronic, inflammatory, demyelinating disorder of the central nervous system (CNS) characterized by episodic and progressive neurologic dysfunction resulting from inflammatory, autoimmune and neurodegenerative processes. According to McDonald MS criteria (introduced in 2001, revised in 2005 and 2010), MS can be divided into four clini-

Correspondence to: Assist. Prof. Iris Zavoreo, MD, PhD, Clinical Department of Neurology, Sestre milosrdnice University Hospital Center, Vinogradska c. 29, HR-10000 Zagreb, Croatia

E-mail: iris_zavoreo@yahoo.com

Received May 4, 2016, accepted June 15, 2016 cal subtypes: relapsing remitting, secondary progressive, primary progressive, and progressive relapsing ${ }^{1}$.

Although multiple sclerosis has historically been considered primarily affecting the CNS white matter, recent pathologic and imaging studies have established that demyelinated lesions are also commonly found in the cortical gray matter of MS patients. Lesions are disseminated throughout the CNS, but have a predilection for optic nerves, subpial spinal cord, brain stem, cerebellum, juxtacortical and periventricular white matter regions. Histologically, several processes drive the formation of MS plaques: inflammation, myelin breakdown, astrogliosis, oligodendrocyte injury, neurodegeneration and remyelination ${ }^{1,2}$. 
The normal male sexual response cycle can be divided into libido (sexual desire), erection, ejaculation, orgasm and detumescence. In female, sexual response cycle has four elements, i.e. libido, arousal, orgasm and satisfaction. The integrity of the sexual response cycle is essential to human sexual response and functioning, and any damage may result in sexual dysfunction (SD).

Sexual arousal begins in the CNS, the brain sends messages to the sexual organs along the nerves running through the spinal cord (descending pathways), as well as receiving information from genital organs (ascending pathways). If MS damages these pathways, sexual response, including arousal and orgasm, can be directly affected (direct physical influence on SD). Sexual problems also stem from MS symptoms such as chronic pain, fatigue or spasticity, as well as dysfunction of urinary system (frequency, urgency, incontinence and obstructive symptoms) as indirect physical influence on SD. Also, it is of great importance to bear in mind that emotions are the result of complex functional circuits in the brain including interactions of the cortical, subcortical structures and limbic system. Sexual dysfunction can also arise from psychological factors relating to self-esteem and mood changes as a consequence of decreased quality of life and social functioning as emotional and cultural influence on SD. In large studies, depression was the most frequent SD comorbidity in MS patients $\mathrm{s}^{3-5}$.

The prevalence of SD in the general population is $31 \%$ in men and $43 \%$ in women. Multiple sclerosis is associated with an increased incidence of $\mathrm{SD}$, present in $50 \%-75 \%$ of men and $40 \%-74 \%$ of women. The rate of major depressive disorder (MDD) in MS patients was found to be from $36 \%$ to $54 \%$ during lifetime. The syndrome refers to a collection of signs and symptoms underlain by low mood and inability to enjoy life as before. This change can be accompanied by a number of vegetative features (altered sleep, appetite, etc.) and distorted beliefs (feelings of guilt, worthlessness, life is not worth living, etc.). Both SD and depression are very often under-recognized, but have considerable impact on the patient quality of life. Therefore, in the evaluation of patients with MS, it is of great importance to pay attention not only to functional deficit, but also to mood changes, SD and quality of life ${ }^{6-11}$.

Due to the complexity and multifactorial nature of SD and its clinical manifestations, multidisciplinary approach is of great importance in MS patients, in- cluding neurologist, physical therapist, psychiatrist, urologist and educated nurses.

\section{Patients and Methods}

The present study included 98 patients aged 18-60 years from our Neurology Department MS register. All patients had established diagnosis of relapsing remitting multiple sclerosis according to $\mathrm{McD}$ onald criteria with EDSS score 0-4 (fully ambulatory patients). Patients completed the questionnaires (Sexual Satisfaction Scale, SSS and Beck Depression Scale, BDS), and underwent neurological assessment (Expanded Disability Status Scale, EDSS). Before establishment of the MS diagnosis, patients had no psychiatric diagnosis or treatment. Patients were not taking antidepressants and there was no statistically significant difference in taking other symptomatic therapy (pain, spasms, bladder and sphincter control).

The Sexual Satisfaction scale is based on the Sexual History Form (Nowinski and LoPiccolo, 1979). Four items from the Sexual History Form were selected to provide an indicator of overall sexual adjustment. These items address the degree of satisfaction with physically expressing affection; the variety of sexual activities engaged in; and with the sexual relationship in general. The fourth item addresses the perceived level of satisfaction experienced by the partner within the relationship. This four-item scale is one of the components of the Multiple Sclerosis Quality of life (MSQLI). Raw scores on the 4 sexual satisfaction items (items 2-5) are summed to create total score. Thus, this scale can range from 4 to 24 . Higher scores indicate greater problems with sexual satisfaction.

The Beck Depression Inventory (BDI, BDI-II), created by Dr. Aaron T. Beck, is a 21-question multiple-choice self-report inventory that is one of the most widely used instruments for measuring the severity of depression. The latest version of the questionnaire is designed for individuals aged 13 and over and is composed of items relating to depression symptoms such as hopelessness and irritability, cognitions such as guilt or feelings of being punished, as well as physical symptoms such as fatigue, weight loss, and lack of interest in sex. There are three versions of the BDI: the original BDI first published in 1961 and later revised in 1971 as BDI-1A, and the BDI-II published in 1996. Like BDI, the BDI-II also contains 21 questions, each an- 
swer being scored on a scale of 0 to 3 . The cutoffs used differ from the original: $0-13=$ minimal depression; 14-19 = mild depression; $20-28$ = moderate depression; and $29-63=$ severe depression. Higher total scores indicate more severe depressive symptoms.

The Expanded Disability Status Scale (EDSS) is evaluating the degree of neurologic impairment in MS; it is a combination of grades $(0=$ normal to 5 or 6 = maximal impairment) within 8 Functional Systems (FS) and an overall Disability Status Scale (DSS) that have steps from 0 (normal) to 10 (death due to MS). The FS are Pyramidal, Cerebellar, Brain Stem, Sensory, Bowel \& Bladder, Visual, Cerebral (Mental). Total EDSS score varies from 0-normal to 10-death due to MS.

The research was approved by the Sestre milosrdnice University Hospital Center Ethics Committee. All patients signed the informed consent form for participation in the study, as well as permission for publishing the data.

\section{Results}

All patients were in the group with EDSS 2 to 4 points (fully ambulatory patients) and all were young adults (interval 23-47 years). There were 42 men and 56 women. Duration of the disease was $5 \pm 1.5$ years. According to the level of education, there were $45 \%$ of patients with university degree, $37 \%$ with secondary school and $18 \%$ with elementary school. Most of the patients were single or divorced (no statistically significant differences according to gender; $p>0.05$ ). Despite low EDSS score, only $23 \%$ of study patients were working full time, whereas almost two-thirds were working half time or retired/unemployed (Table 1). There was no statistically significant difference in BDS and SSS values according to gender, disease duration or immunomodulatory therapy $(\mathrm{p}>0.05)$.

Symptoms of depression were identified in $57 \%$ of patients (no gender differences; $p>0.05$ ), and symptoms of $\mathrm{SD}$ in $71 \%$ of patients (no gender differences; $\mathrm{p}>0.05)$. Most of men reported erectile dysfunction (31\%), while the lack of sexual desire (20\%) and orgasm problems (13\%) were less frequently reported. In women, the lack of sexual desire was mostly frequently reported (25\%), while orgasm problems (21\%) and lubrication problems (20\%) were less frequently reported.
Table 1. Demographic data of multiple sclerosis patients

\begin{tabular}{|l|c|}
\hline $\begin{array}{l}\text { Age (years) } \\
\text { (mean } \pm \text { SD) }\end{array}$ & $35 \pm 12$ \\
$\begin{array}{l}\text { Gender, men/women } \\
\text { (number of patients) }\end{array}$ & $42 / 56$ \\
$\begin{array}{l}\text { Disease duration (years) } \\
\text { (mean } \pm \text { SD) }\end{array}$ & $5.0 \pm 1.5$ \\
\hline $\begin{array}{l}\text { Level of education } \\
\text { (number of patients; percent) }\end{array}$ & $17(18 \%)$ \\
$\begin{array}{l}\text { Elementary school } \\
\text { Secondary school }\end{array}$ & $36(37 \%)$ \\
University & $45(45 \%)$ \\
\hline $\begin{array}{l}\text { Marital status } \\
\text { (number of patients; percent) }\end{array}$ & $32(32.6 \%)$ \\
Married & $28(28.5 \%)$ \\
Single & $38(38.7 \%)$ \\
Divorced & \\
\hline $\begin{array}{l}\text { Working status } \\
\text { (number of patients; percent) }\end{array}$ & $25(25.5)$ \\
Retired/unemployed & $50(50.7)$ \\
Half time & $23(23.6)$ \\
Full time
\end{tabular}

Table 2. Depression symptoms and sexual dysfunction scores of multiple sclerosis patients

\begin{tabular}{|l|c|}
\hline $\begin{array}{l}\text { Beck Depression Scale score } \\
(\text { mean } \pm \text { SD) }\end{array}$ & \\
Men & $14.1 \pm 1.2$ \\
Women & $16.2 \pm 3.1$ \\
\hline SSS score (mean \pm SD) & \\
Men & $10 \pm 2.2$ \\
Women & $12.1 \pm 3.5$ \\
\hline Beck Depression Scale & \\
/Sexual Satisfaction & \\
Scale correlation coefficient & \\
Men & 0.42 \\
Women & 0.44 \\
\hline
\end{tabular}

The Beck Depression Scale score for both men and women was in the range for mild depression, and SSS score in the range for moderate SD (no differences according to gender; $p>0.05$ ).

Chronic fatigue was identified n $64 \%$ (no gender differences), bladder and sphincter control disturbances in 34\% (no gender differences), and spasticity in $42 \%$ of patients (no gender differences) ( $p>0.05$ all). 
There was no statistically significant difference in BDS and SSS values according to EDSS score $(p>0.05)$. Correlation coefficients were calculated (BDS and SSS) for men $(\mathrm{p}=0.42)$ and for women $(\mathrm{p}=0.44)$, yielding positive correlation (Table 2$)$.

\section{Discussion}

Our study patients were young adults aged 23-47 and mobile, with EDSS score 2-4. Only one-third of patients were married and one-third had full time working hours. The incidence of depression was slightly higher in our study than in previous studies $(57 \%$ vs. $50 \%$ ), and SD was present at a high percentage, but not higher than in other studies (71\% vs. 40\%-75\%). These data indicate that despite low EDSS functional score which reflects direct and indirect physical impact on $\mathrm{SD}$, there is a high emotional and cultural influence on $\mathrm{SD}^{12,13}$.

We found positive correlation for both genders between depression and SD. Miscellaneous factors are involved in the incidence of depression and SD in MS patients. According to large studies, there does not appear to be clear genetic predisposition for major depression and SD in MS patients. Structural changes confirmed on MRI of the brain and spine are in correlation with previously described pathomorphological and functional mechanisms of depression and SD. Psychosocial factors are of great importance in the evaluation of depression and SD in MS patients. A major limiting factor is that studies evaluating the impact of these factors are cross sectional, lacking follow up data ${ }^{10-12}$. Results of these studies have shown that the most important problem in the evaluation and treatment of MS patients with depression and SD is focus on emotion/state rather than the problem that has caused it. In order to resolve depressive mood and $\mathrm{SD}$, a multidisciplinary approach should be used. The evaluation and treatment should also include functional status of the patient (EDSS score), as well as individual approach in planning medical treatment of MS, symptomatic treatment (bladder and sphincter control, pain, spasms) and coping strategies, recreational opportunities, improvement of relationships, and reduction of physical and psychical stress (chronic fatigue). In addition, it is of great importance to take in consideration disturbances of the hypothalamic-pituitary-adrenal axis, as well as the hypothalamic-pitu- itary-gonadal axis with disturbances of mood (depressive disorder) and $\mathrm{SD}$ as consequences ${ }^{13}$.

Despite pronounced depression in MS patients, there are few well constructed psychopharmacological studies (the Cochrane Multiple Sclerosis Group's Trial Register contains only 2 studies the methodology of which, i.e. randomized, controlled, double blinded study, is considered appropriate). In these two studies, tricyclic antidepressants and serotonin reuptake inhibitors (SSRI) were proven to have positive impact on regression of depressive symptoms in MS patients versus placebo group. On subsequent screenings, patients reported fewer depressive symptoms regardless of whether a formal treatment recommendation was documented. These findings suggest that while depression screening does lead to depression related intervention in many cases, additional research is necessary to determine who is most likely to benefit and under what conditions ${ }^{13,14}$.

In the evaluation of MS patients, depression and SD symptoms should be evaluated and appropriately treated with individual, but also multidisciplinary approach in order to improve their quality of life. There is a need of follow up studies to evaluate the impact of different physical, functional and psychosocial factors, as well as the impact of rehabilitation, immunomodulatory therapy and symptomatic therapy on long term outcome and quality of life in MS patients ${ }^{14-16}$.

\section{References}

1. Bašić Kes V, Zavoreo I, Šerić V, Vargek-Solter V, Cesarik M, Hajnšek $S$, Bošnjak-Pašić $M$, Gabelić $T$, Bašić $S$, SoldoButković S, Lušić I, Dežmalj-Grbelja L, Vladić A, Bielen I, Antončić I, Demarin V; Croatian Society for Neurovascular Disorders of Croatian Medical Association; Croatian Society of Neurology of Croatian Medical Association; Referral Center for Demyelinating Diseases of the CNS. Recommendations for diagnosis and management of multiple sclerosis. Acta Clin Croat. 2012;51(1):117-35.

2. Popescu BF, Pirko I, Lucchinetti C. Pathology of multiple sclerosis: where do we stand? Continuum J. 2013;19(4):901-921. doi: 10.1212/01.CON.0000433291.23091.65

3. Vidović V, Časar Rovazdi M, Kraml O, Bašić Kes V. Pseudobulbar affect in multiple sclerosis patients. Acta Clin Croat. 2015;54(2):159-63.

4. Bašić Kes V, Čengić L, Cesarik M, Tomas-Jadrijević A, Zavoreo I, Matovina-Zadro L, Ćorić L, Drnasin S, Demarin V. Quality of life in patients with multiple sclerosis. Acta Clin Croat. 2013;52(1):107-11. 
5. Bašić Kes V, Cesarik M, Matovina-Zadro L, Zavoreo I, Corić L, Drnasin S, Demarin V. The role of complementary and alternative medicine in therapy of multiple sclerosis. Acta Clin Croat. 2013;52(4):464-71.

6. Azimian M, Shahvarughi-Farahani A, Rahgozar M, Etemadifar M, Nasr Z. Fatigue, depression, and physical impairment in multiple sclerosis. Iran J Neurol. 2014 Apr 3;13(2):105-7.

7. Induruwa I, Constantinescu CS, Gran B. Fatigue in multiple sclerosis - a brief review. J Neurol Sci. 2012;15;323(1-2):9-15. doi: 10.1016/j.jns.2012.08.007

8. Feinstein A, Magalhaes S, Richard JF, Audet B, Moore C. The link between multiple sclerosis and depression. Nat Rev Neurol. 2014;10(9):507-17. doi: 10.1038/nrneurol.2014.139

9. Fragalà E, Russo GI, Di Rosa A, Giardina R, Privitera S, Favilla V, Castelli T, Chisari M, Caramma A, Patti F, Cimino S, Morgia G. Relationship between urodynamic findings and sexual function in multiple sclerosis patients with lower urinary tract dysfunction. Eur J Neurol. 2015 Mar;22(3):485-92. doi: 10.1111/ene. 12595

10. Lew-Starowicz M, Rola R. Correlates of sexual function in male and female patients with multiple sclerosis. J Sex Med. 2014;11(9):2172-80. doi: 10.1111/jsm.12622

11. Prévinaire JG, Lecourt G, Soler JM, Denys P. Sexual disorders in men with multiple sclerosis: evaluation and management.
Ann Phys Rehabil Med. 2014;57(5):329-36. doi: 10.1016/j. rehab.2014.05.002

12. Ashtari F, Rezvani R, Afshar H. Sexual dysfunction in women with multiple sclerosis: dimensions and contributory factors. J Res Med Sci. 2014 Mar;19(3):228-33.

13. Pucak ML, Carroll KA, Kerr DA, Kaplin AI. Neuropsychiatric manifestations of depression in multiple sclerosis: neuroinflammatory, neuroendocrine, and neurotrophic mechanisms in the pathogenesis of immune-mediated depression. Dialogues Clin Neurosci. 2007;9(2):125-39.

14. Schumann R, Adamaszek M, Sommer N, Kirkby KC. Stress, depression and antidepressant treatment options in patients suffering from multiple sclerosis. Curr Pharm Des. 2012;18 (36):5837-45.

15. Stepleman LM, Penwell-Waines LM, Rollock M, Casillas RS, Brands T, Campbell J, Ange B, Waller JL. Routine depression screening in an MS clinic and its association with provider treatment recommendations and related treatment outcome. J Clin Psychol Med Settings. 2014;21(4):347-55. doi: 10.1007/ s10880-014-9409-0

16. Lisak M, Demarin V, Trkanjec Z, Zavoreo I, Bašić Kes V. Person-oriented perspectives in neurology. Acta Clin Croat. 2014; 53(4):423-9.

Sažetak

\section{SEKSUALNA DISFUNKCIJA I INCIDENCIJA DEPRESIJE U BOLESNIKA S MULTIPLOM SKLEROZOM}

\section{Zavoreo, T. Gržinčić, M. Preksaveci V. Bašic Kes}

Multipla skleroza (MS) je jedna od najčešćih bolesti središnjeg živčanog sustava, a najčešće se javlja u mlađoj životnoj dobi kada su bolesnici seksualno aktivni. U svakodnevnoj praksi seksualna disfunkcija biva podcijenjena jer se kliničari uglavnom fokusiraju na klasične neurološke ispade te najčešće ne prepoznaju simptome koji mogu značajno umanjiti kvalitetu života bolesnika. U našu studiju je bilo uključeno 98 bolesnika (42 muškarca i 56 žena, srednje dobi $35 \pm 12$ godina) s dijagnosticiranim relaps remitentnim oblikom multiple skleroze prema McDonaldovim kriterijima. Bolesnici su ispunili standardizirane upitnike (Sexual Satisfaction Scale, SSS i Beck Depression Scale, BDS) kako bi se procijenile depresivne tegobe i seksualna disfunkcija, a provedeno je i neurološko testiranje pomoću funkcijske ocjenske skale (Expanded Disability Status Scale, EDSS). Svi bolesnici su bili pokretni i imali EDSS zbroj između 2 i 4. Nije bilo razlike u BDS i SSS vrijednostima u odnosu na EDSS zbroj. Koeficijenti korelacije za BDS i SSS su izračunati za muškarce $(p=0,42)$ i žene $(p=0,44)$ i pokazali su pozitivnu korelaciju. Nije nađeno statistički značajnih razlika za BDS i SSS vrijednosti u odnosu na spol, duljinu trajanja bolesti te vrstu imunomodulacijske terapije. U našoj skupini ispitanika, unatoč niskom EDSS zbroju (pokretni bolesnici, sposobni se brinuti o sebi) nađena je pozitivna korelacija između depresije i seksualne disfunkcije, što ukazuje da i u takvih bolesnika kvaliteta života može biti znatno narušena. Možemo zaključiti kako su seksualna disfunkcija i depresija neki od najčešće podcijenjenih simptoma od strane neurologa jer nisu dio rutinskih testiranja. Potrebno je u rutinsku evaluaciju bolesnika s MS uključiti dodatne upitnike kako bi se procijenila kvaliteta života bez obzira na njihov EDSS zbroj.

Ključne riječi: Multipla skleroza; Spolna disfunkcija, fiziološka; Spolna disfunkcija, psibološka; Depresija 